\title{
Methodological Signatures in Early Ethology: The Problem of Animal Subjectivity
}

\author{
Anna Klassen ${ }^{1}$ D
}

Accepted: 18 January 2021 / Published online: 24 June 2021

(C) The Author(s) 2021

\begin{abstract}
What is the adequate terminology to talk about animal behaviour? Is terminology referring to mental or emotional states anthropomorphic and should therefore be prohibited or is it a necessary means to provide for an adequate description and should be encouraged? This question was vehemently discussed in the founding phase of Ethology as a scientific discipline and still is. This multi-layered problem can be grasped by using the concept of methodological signatures, developed by Köchy et al. (2016c). It is designed to analyse and systematically compare animal research approaches by examining their common parameters. By examining the works of Konrad Lorenz (1903-1989) and Nikolaas Tinbergen (1907-1988), this paper offers new insights both on a methodological and theoretical level. Methodologically, the application of the concept of methodological signatures is illustrated; theoretically, the principles of Classic Ethology are analysed. My aim is to illustrate how the problem of scientific access to animal subjectivity was addressed in the history of Ethology by analysing statements about animal sentience. For this purpose, I will first outline the general discussion about animal subjectivity and the tension between anthropomorphism and empirical adequacy. I introduce my own theoretical and methodological framework before presenting an analysis of Lorenz' and Tinbergen's methodological signatures. Thereby, I show how the question of terminology is deeply embedded in a network of epistemological, methodological and ontological concepts and establish key characteristics in regard to ethological approaches to animal subjectivity. Finally, I shed light on the possibility of using this typology to examine current frameworks of animal welfare research.
\end{abstract}

Keywords Konrad Lorenz · Nikolaas Tinbergen · Animal behaviour · Animal subjectivity

Anna Klassen

anna.klassen@uni-jena.de

1 Lehrstuhl für Geschichte und Philosophie der Naturwissenschaften mit dem Schwerpunkt

Lebenswissenschaften, Friedrich-Schiller-Universität Jena, Jena, Germany 


\section{Introduction}

Since its beginning, behavioural research has been confronted with the question of the methodological, terminological and ontological problem of other minds ${ }^{1}$ in the investigation of non-human animals (hereafter referred to as animals) (Böhnert and Hilbert 2018, 4-7). The ability to have experiences that are directly accessible only to the experiencing entity itself, e.g. emotions, intentions or thoughts, was discussed regarding either its sheer existence, observability or in which way it could be adequately designated. These experiences are hereinafter grouped together under the concept of animal subjectivity. An ongoing discussion in the study of animal behaviour is about the question, whether subjective states could be scientific research objects at all, if some could and other not.

Denial of animal subjectivity has its roots in Cartesian subject philosophy (Kurth 2016, 18). Descartes' mind-body-dualism and his thesis that animals (in contrast to humans) are machines are regarded as central components of a narrative in animal research according to which animals are mere corporeal beings without any sentience (Schmitz 2014, 34; Wild 2013, 44-53; Toepfer 2011, 494). Yet, this strong form of anthropological difference ${ }^{2}$ was difficult to maintain in its original form due to the notion of phylogenetic kinship in the theory of evolution. Today, the evolutionary continuity between non-human and human animals is a widely recognized scientific fact that, on its own, has to be considered with regard to definitions of anthropological difference (Wild 2013, 54-59).

The purpose of stressing the anthropological difference in behavioural research is the avoidance of anthropomorphism, i.e. "the attribution of human characteristics (including the projection of subjective states and feelings) to non-human entities" (Morton et al. 1990, 13). Thereby, the scientific nature of animal behavioural research is supposed to be secured (Hilbert 2018, 141-142). Throughout Ethology's history as a discipline, efforts were made to distance it from other behavioural research that explicitly used employed subjective states as explanations for animal behaviour, such as Animal Psychology (Toepfer 2011, 466-467) or Natural History (Wuketits 1995,24$).{ }^{3}$ On the other hand, there are also voices arguing for critical and reflective anthropomorphism (Wild 2013, 73; Böhnert and Hilbert 2018), or, by coining the counter-term "anthropodenial", criticise the a priori rejection of possible common characteristics of humans and animals (Waal 2006, 59-67). Especially in animal welfare research there is an ongoing discussion about the possibility of assessing animals' subjective states (Wemelsfelder 1997; Lijmbach 1998; Proctor et al. 2013).

This paper portrays how the problem of scientific access to animal subjectivity was addressed in the early history of Ethology by analysing selected research approaches in which the (de)legitimisation for the use of subjective terminology is discussed. By examining the works of Konrad Lorenz (1903-1989) and Nikolaas Tinbergen (1907-1988), this paper offers new insights both on a methodological and on a theoretical level. Methodologically, the application of the concept of methodological signatures is illustrated;

\footnotetext{
1 I use a broad concept of "mind", referring not only to cognitive, but also to emotional and intentional states, and sentience.

2 "Anthropological difference" describes the characteristic(s) by which humans are essentially different from all other animals (Wild 2013, 25-28).

3 The term "Ethology" stems from Oskar Heinroth, one of Lorenz' mentors and is closely connected to Lorenz' research approach since the 1930s (Toepfer 2011, 462, 467). As the disciplinary boundaries were still a matter of controversy in the historic period this paper covers (Meyer-Holzapfel 1984), the terms "Animal Psychology" or "Comparative Psychology" are also used by Lorenz and Tinbergen to refer to their field of research.
} 
theoretically, the principles of Classic Ethology are analysed according to this concept. Finally, the systematic usefulness of the historical analysis is presented. By application of the key characteristics of Classical Ethology to a fairly new method in animal welfare research called Qualitative Behaviour Assessment, I will show both the applicability of the developed framework as well as shed light on possible modifications to animal behaviour research in the 21 st century.

\subsection{Methodological Signatures}

My approach based on the philosophical concept of methodological signatures. This programmatic concept of philosophy of science was developed in the interdisciplinary field of human-animal-studies (Köchy et al. 2016c; 2016b, 81; 2016a, 359-360). In tradition of a contextual approach in philosophy of science, as established in history and sociology of science (e.g. Fleck 1981 or Latour 1987), a complex framework of foundational assumptions can be generated (Böhnert 2020, 95). For this, the interaction of parameters of a research approach is examined, i.e. "the specific combination of the explicit and implicit key characteristics" (Böhnert and Hilbert 2018, 3). A none-exhaustive list of potential key characteristics contains preferred reference animals, their primarily investigated abilities, methodology, research locations, the underlying scientific ideal, the positioning in relation to other research approaches and the philosophical background assumptions and implications (Köchy et al. 2016c, 14). In the case of historical research approaches, those key characteristics are inferred from scientific texts which address a similar research problem. The concept of methodological signatures is a tool for the analysis and comparison of different scientific approaches in animal research (Böhnert 2020, 94), that do not have to be similar content-wise. On the contrary, it can be assumed that the basic presumptions are more apparent in the case of controversies (Böhnert 2020, 16). This applies also to the present case, since Lorenz and Tinbergen strive to set their research approach apart from both Animal Psychology and Behaviourism with emphasis on the question of animal subjectivity. Due to the notion of research approaches as complex structures of explicit and implicit methodology, epistemology and ontology, the (de)legitimisation of subjective terminology is not only about terminology.

The aim of this paper is to show the network of epistemological, methodological, and ontological assumptions in which such (de)legitimation strategies are embedded. This is carried out by analysing statements about animal experience in the research of Konrad Lorenz and Nikolaas Tinbergen who laid the methodological and conceptual groundwork for Ethology as a discipline. In the first half of the twentieth century, Lorenz and Tinbergen presented themselves as scientists between two extremes of the spectrum of animal behaviour research, namely Animal Psychology and Behaviourism. ${ }^{4}$ They demarcated their research approach as the middle ground of those positions. Classical Ethology is presented by Lorenz and Tinbergen as a scientific discipline that does not make the same mistakes as its competitors, those mistakes being either anthropomorphism (Animal Psychology) or reductionism (Behaviourism). They understood their own approach as capable of detailed analysis due to two factors: Its conceptual foundation in evolutionary theory and its methodology that prioritises being close to the phenomena in question.

\footnotetext{
4 These classifications are actors' categories. Since I am interested in the arguments for demarcation against the two other disciplines, I use these stereotypical categorisations.
} 


\section{Lorenz' and Tinbergen's Methodological Signatures}

Before presenting Lorenz' and Tinbergen's respective methodological signatures it should be pointed out that Tinbergen distinguishes more clearly between programmatic and research writings than Lorenz. Lorenz, in turn, does theorize to a greater extent than Tinbergen. He is also the one who stages his life with animals in a sensational way parallel to his research on animals (Meyer-Holzapfel 1984, 23-24; Tinbergen 1978, 139-140). Tinbergen, on the other hand, plays the role of the empirical researcher who always maintains distance from his research objects (Burkhardt 2005, 188). Thus, Lorenz is seen, in the scientific community as well as in the public, as the driving force behind the establishment of Ethology, even by Tinbergen himself:

“[Lorenz] has made us apply 'biological thinking' to a phenomenon to which it had hitherto not been as consistently applied as was desirable. [...] I also submit that this is an achievement of tremendous importance and that, if anything deserves the much-abused name of 'a major break-through', Lorenz' [sic] achievement does.' (Tinbergen 1963, 411).

\subsection{Lorenz}

The core of Lorenz' theory is the concept of instinct. He defines instinct as an innate neurophysiological reaction (Lorenz 1965d, 346-350), and sharply distinguished it from learned behaviour (Burkhardt 2005, 147). In this regard, Lorenz is also interested in the reconstruction of phylogenetic relationships on the basis of behavioural characteristics (Burkhardt 2005, 146). His initial goal was to integrate evolutionary explanation into the discipline of Animal Psychology (Lorenz 1937). This orientation was the basis for the cooperation between Lorenz and Tinbergen. Both agreed that Ethology should not deal with subjective experiences of animals (Burkhardt 2005, 204).

The most prominent difference between Tinbergen and Lorenz is the uniformity of their theories. In Lorenz' post-war-writing, a departure from the strong claim to reject animal subjectivity can be observed (Cranach and Lorenz 1992) (English translation: Lorenz and Cranach 1996). Here, he attempts to unite the natural sciences and the humanities (Burkhardt 2005, 279). This is also associated with a new way of looking at animal subjectivity (Lorenz 1966a) and the development of the concept of evolutionary epistemology.

Lorenz' "Kumpan"-monograph is regarded as the elaboration of his fundamental ethological concepts; above all the concept of instinct (Eibl-Eibesfeldt 1984, 67; Lorenz 1965b, 124) and Comparative Psychology of Perception (Burkhardt 2005, 164). Ontological and methodological statements are mostly used in the context of justification of Lorenz' instinct theory, for the demarcation against predominant Animal Psychology positions and for the further development of Uexküll's environmental theory. It is noteworthy to say that the concepts of "Kumpan" (companion) and "Umwelt" (environment) used by Lorenz are strongly influenced by Uexküll (Burkhardt 2005, 154-158), but Lorenz puts them in an evolutionary context-in clear opposition to Uexküll. ${ }^{5}$

Lorenz emphasises the practice of "Comparative Psychology as a biological science [translation AK]" (Lorenz 1965b, 124). By this he means the implementation of the idea of the phylogenetic Bauplan (plan or blueprint, another term by Uexküll) to investigate the instinctive behaviour of animals and to distinguish it from intelligent behaviour: "Without

\footnotetext{
${ }^{5}$ However, Lorenz uses evolutionary terms such as species survival primarily to demonstrate that a causal analysis can describe all aspects of behaviour.
} 
exact knowledge of an animal's instinctive plan, one does not even know how difficult the problem is for the animal [translation AK]" (Lorenz 1965b, 124). Instinct, according to Lorenz, is analogous to an organ, not to mental activity and thus determined by the Bauplan (Lorenz 1965b, 274).

To distinguish instinct movements correctly from learned behaviour Lorenz formulates methodological requirements for good scientific practice in Ethology. The methodological theses of the pre-war works emphasize the value of long-term observation (Burkhardt $2005,147)$ and experience based on scientific intuition: „In general, a somewhat experienced animal keeper recognizes instinct behaviour of his fosterlings, as far as one recognizes them at all, without any further thought completely emotionally as such [translation AK]" (Lorenz 1965a, 89).

While the pre-war works served positioning himself in relation to a developing scientific community, Lorenz' writings from the war on are considered the "conception of a comparative behavioural research [...] in its essential theoretical components [translation AK]." (Wunsch 2016, 278) Explicit ontological declarations and methodological theses can be found here. One of them is the statement that " $\mathrm{t}] \mathrm{h}$ he universe is governed by a hierarchical framework of natural laws in which broader, simpler principles are always incorporated into the narrower ranges of validity of special, more complex principles, because they [the simple principles, AK] provide the foundations for them [the more complex principles, AK]" (Lorenz and Cranach 1996, 40).

Lorenz' concept of evolution fits the model of the hierarchical framework of natural laws. He stresses the idea of the "history of the organic, determined by a unique and genuine causal process, that let complex systems emerge from simpler ones. Simpler entities have always been the cause of more complex entities and not vice versa. All living beings are historical beings, and a real understanding of their being [So-Sein] is only possible on the basis of a historical understanding of the unique process of evolution that led to their development towards this and no other form [translation AK]" (Lorenz 1965c, 383).

Let me lead over to the question of terminology that is associated with the theoretical assumptions of instinct, the methodological requirements and the strong emphasis on the evolutionary framing of biological research.

Statements about animals' inner life accumulate in the later writings of Lorenz. He refers to animal subjectivity as a necessary premise to describe animal behaviour adequately and comprehensively in certain species. There, Lorenz rejects Behaviourism's physical reductionism (Lorenz 1978, 17) and the Cartesian mind-body-dualism in favour of what he describes as psychophysical parallelism (Cranach and Lorenz 1992, 157, 233-234), but would rather be more correctly defined as psychophysical monism.

"As inductively operating natural scientists, we must base our conclusions regarding the relationship between mind and body in the undoubted, universally evident empirical fact that spiritual [better: mental, AK] processes simply do not exist without parallel processes operating [better: occuring, AK] in a living organism [...]" (Lorenz and Cranach 1996, 158). According to Lorenz, subjective states are functions of living organisms (Cranach and Lorenz 1992, 156). Thus, they must be regarded as products of evolution (Cranach and Lorenz 1992, 153).

Starting from this understanding of evolution, Lorenz asks for the survival value of subjective states. He finds it in experiencing pleasure and pain, since they are necessary 
preconditions for modifiable behaviour in the sense of learning. Thus, e.g. operant conditioning of animals by "carrot and stick" is based on subjectivity, namely on the distinction between pleasant and unpleasant stimuli (Cranach and Lorenz 1992, 242). The physiological preconditions for this are complex sensory organs and a central nervous system (Cranach and Lorenz 1992, 244), so this form of subjectivity can occur e.g. in mammals or birds.

The possibility of inferring the existence of subjective states in animals from the survival value of pleasure and pain leads Lorenz to the proposition that, in higher animals, instinct movement is linked with a subjective state, called Funktionslust (pleasure of functioning (Lorenz 1966b, 337)). It is defined as the self-rewarding function of endogenous automatic movements that makes animals surge for the triggering stimulus for the movement and thus serving the survival value of the instinct movement (Lorenz 1965c, 390-391).

Examining Lorenz' methodological signature on the basis of his notion of animal subjectivity leads to the conclusion that his concept of animal subjectivity is broad. It ranges from the simple difference of pain and pleasure to the ability for informed decision making (Lorenz 1965b, 131), ${ }^{6}$ so from what may be called very basic emotional states to high mental performances. But not only animal subjectivity is a benchmark in Lorenz' methodological signature, human subjectivity is important as well. It plays a role in Lorenz' biologised epistemology to that extent that long-term observation, expertise and emotional commitment in combination with physiological, physio-chemical approaches lead to scientifically valuable results.

\subsection{Tinbergen}

Tinbergen's approach of defining Ethology through the questions it asks is fundamental to the identity of this scientific discipline (Burkhardt 2005, 12) and is still taught today (e.g. (Kappeler 2017, 4-5; Naguib 2006, 8). In his 1963 article "On aims and methods of Ethology" he states that Ethology should be able to answer the questions concerning causation, survival value, evolution and ontogeny of behaviour. Causation and ontogeny have to be investigated at the level of the individual animal, evolution and survival value at the level of the population.

There theoretical demands are based on Tinbergen's methodology that insists on a certain concept of objective research (Wuketits 1995, 77), proximity to natural phenomena (Tinbergen 1963, 411) and a consistent, self-restrained methodology (Tinbergen 1942, 93). According to Tinbergen, "Comparative Ethology consciously returns to a sounder mode of approach [than Behaviourism, AK], in which the problem again is primary, the method secondary." (Tinbergen 1942, 42) The basis for this kind of research are observation data collected over many years by experienced field workers. Good ethologists are "good naturalists" (Tinbergen 1963, 427) who, through experience with the observed animals, perceive more behavioural details and also have knowledge of the biological value of behaviour in relation to the environment. Although the animal is the clear focus of Ethology, it should not be treated as an isolated object.

\footnotetext{
6 Since Lorenz is not interested in researching animal intelligence, he only mentions it as a possible capacity of higher animals such as parrots or chimpanzees.
} 
Tinbergen also takes in consideration the relation of observation and theory building. He makes three methodological claims:

1. "First, there is a need for ever increasing detailedness." (Tinbergen 1942, 43) According to Tinbergen, it is necessary to get a complete overview of how many and which elements one kind of behaviour consists of, since it can consist of different individual movements. Tinbergen contrasts this approach with that of Animal Psychology, whose aim it is to investigate animal emotions and therefore only deals with movements that are considered to be the expressions of emotions (Tinbergen 1942, 44). According to Tinbergen, however, subjective factors as emotions cannot be objectively understood, which is why, as causal factors, they must not play any role in objectivistic research (Tinbergen 1966, 4-5).

2. "Secondly, consideration of the whole behaviour pattern of a species is necessary" (Tinbergen 1942, 43). Even in one species the comparison between different kinds of behaviour can lead to meaningful and exhaustive insights. "Knowledge of the whole behaviour-pattern of a species saves us from seeing a controversy in what is actually differentiation" (Tinbergen 1942, 45).

3. "Thirdly, comparison of behaviour patterns of a species is necessary" (Tinbergen 1942, 43). Tinbergen seeks to avoid monolithic explanations and instead points out the requirement of an accurate overview of the causal factors of behaviour (Tinbergen 1942, 46). For this reason, the research method must always be adjusted to the examined species-otherwise there is a risk of erroneous analogy under the pretence of an overall, non-species-specific generalisation (Tinbergen 1966, 14). This implicates a discontinuous understanding of evolution - the premise is that each species' behaviour should be foremost recognised in regard to its current inner and outer conditions, in contrast to a historical comparative analysis of behaviour.

Tinbergen's objective is to address the inconsistency of contemporary Ethology by clarifying its questions. According to him, the foundation of all ethological thinking should be based in the understanding Ethology as "the biological study of behaviour" (Tinbergen 1963, 411). The question that precedes all ethological research is: "Why do these animals behave as they do?" (Tinbergen 1963, 411). This question is synonymous to: "What are the causes of [their] movements?" (Tinbergen 1942, 49-50). The goal of Ethology is to uncover the individual causal factors and to explain their origin. The system of causal factors is built on the basis of the "major biological problem", which are the problems of (1) causation, (2) survival value, (3) ontogenesis and (4) evolution (Tinbergen 1963, 411).

Subjective terminology in the sense of assumptions about purposiveness of behaviour is a precarious issue for Tinbergen in so far as there is a danger of a false attribution of intentionality, in the sense of: The animal is aware of the function of behaviour and wants to bring about its purpose intentionally. The possibility of fallacy is also embedded in Tinbergen's notion of intertwined causalities: Inferring from I know from myself a behaviour pattern with the goal $X$ to If an animal reaches $X$ with the motion sequence $A B C$, then it $A B C$ is $X$ behaviour does not take into consideration that $\mathrm{B}$ may not contribute to $\mathrm{X}$ at all, but may be a factor whose effect is $\mathrm{Y}$ or which even has no function at all.

So, the use of subjective terminology is, according to Tinbergen, an obstacle in the precise study of the relationship of the various causal factors of behaviour. 


\section{Key Characteristics in Regard to Ethological Approaches to Animal Subjectivity}

Having identified the demands Lorenz and Tinbergen make on ethological research, I will now present the key characteristics of their respective methodological signatures. The key characteristics are phrased as problems the methodological signatures address in their specific way.

Lorenz and Tinbergen, distancing themselves from both Animal Psychology and Behaviourism, which stand for the two poles of approaches to animal subjectivity in Ethology: Tinbergen demands a strict rejection of subjective concepts in an objective scientific research approach, Lorenz provides the context-related acceptance of subjective terms in the service of a systematic, species-specific and uniform description of some abilities in some animals in particular in his post-war writings.

Both approaches share the orientation towards evolution and natural science. However, Lorenz adds the orientation towards a broader philosophical framework. Separating himself from Animal Psychology, he justifies subjective terminology methodologically and modifies his philosophical background assumptions in the direction of an epistemological programme. Tinbergen strictly rejects subjective terminology on the basis of methodological and epistemological claims. In this case, too, an evolutionary theoretical framework is invested, largely abstaining from ontological assumptions, but the underlying scientific ideal restricts explanations to causal references and material factors.

On the basis of the approaches to the problem of animal subjectivity, three key characteristics can be identified as constitutive for Lorenz' and Tinbergen's methodological signatures: The concept of phylogenetic kinship, temporal and spatial requirements of research and the semantic content of the concept of subjective terminology. They are characterised as follows:

1. The concept of phylogenetic kinship: Both Lorenz and Tinbergen emphasise the necessity to base Ethology on the concept of evolution. Lorenz understands evolution as a continuum of increasingly complex beings in regard to quantitatively measurable characteristics, but also accentuates the qualitative differences between the species that emerge from the quantitative differences. According to Lorenz, subjectivity can only be assumed on a certain level of materiality, i.e. organisms with a central nervous system and a sophisticated sensory apparatus. The use of subjective terms is therefore only legitimate for certain animal species.

Tinbergen's notion of evolution emphasizes discontinuity and focuses on individual present species. Therefore, it is inadmissible, to explain behaviour of one species by transferring theories that are the result of research on another species.

In addition, the notion of phylogenetic kinship is closely connected to the concept of anthropological difference (Taylor 2011, 267-268): understanding evolution as a continuum is the condition of the possibility of inferring the knowledge about subjective states in humans to other species, if there is no contradictory biological evidence. In contrast, if evolution is understood as discontinuous, one is not allowed to draw conclusions from one species' behavioural patterns to another's.

2. Methodological and spatial requirements: Both Lorenz and Tinbergen stress the importance of long-term observation in the field. Its value lies in the fact that behaviour should be investigated in relation to its function for the individual animal and the species as an outcome of evolution. Both the relationship of the individual behavioural elements to 
each other and the relationship between behaviour and the environment are accessible in this observational situation. Especially Lorenz emphasises the value of research on wild animals and not on domesticated ones, since the latter tend to show dysfunctional behaviour. Additionally, observational expertise, i.e. familiarity with the target species, can only develop in an adequately long observational time. Thus, behavioural research should be carried out long-term.

3. The semantic content of the concept of subjective terminology: Lorenz' methodological signature is characterised by a differentiation in subjective terminology. He discriminates general from specific and emotional from cognitive terms. He rejects specific and cognitive terms, whereas he advocates for the use of general emotional terminology, that is to say the distinction between positive and negative subjective states. On the other hand, Tinbergen regards all propositions about animals' inner life as unscientific. This ranges from emotions to intentionality.

Regarding the application of this key characteristics to research approaches, the semantic content of the concept of subjective terminology must be considered in terms of differentiation and range: Is subjectivity characterised broadly as experience or does it refer to emotion, cognition or even specific experiences like boredom or surprise? And, if subjective terminology is rejected, does this mean all kinds of terms or just a subset?

\section{Outlook on Current Frameworks of Ethological Research in Animal Welfare}

In recent years, animal subjectivity and associated questions about meta-theoretical basic assumptions and methodological principles have emerged in philosophy and other disciplines in the context of human-animal-studies. Applied ethology, a discipline that is traditionally concerned with animal welfare, is central in this debate. ${ }^{7}$ From a philosophy of science perspective, the consideration of recently developed methodologies to adequate grasp animal sentience seem promising (Rault and Doyle 2016, 114-116).

The example chosen for this paper is Qualitative Behaviour Assessment (QBA), because of its already widespread application (Lawrence 2016, 134) and its explicitly programmatic statements. The aim of this section is to apply the developed key characteristics of research approaches that are explicitly concerned with questions regarding animal subjectivity.

QBA was developed by Françoise Wemelsfelder and her collegues in the early 1990s (Lawrence 2016, 139), and is now applied to farm animals (Wemelsfelder et al. 2000; Fleming et al. 2013; Rutherford et al. 2012; Grosso et al. 2016; Minero et al. 2016), but also to zoo animals and pets (Arena et al. 2017), and which has been incorporated into the EU Welfare Quality® project (ISAE Creativity Award 2017).

The aim of QBA is to create an "overt, quantifiable measure for behavioural expression" (Fleming et al. 2013, 87), which involves the use of subjective terms. To legitimise this terminology, the approach applies statistical schematisation techniques (Free Choice Profiling and Geneteal Procrustes Analysis (Wemelsfelder et al. 2001, 211-213)) to terms that are supposed to describe the "expressive state" (Wemelsfelder et al. 2001, 210) of an animal.

\footnotetext{
7 Another discipline is Cognitive Ethology which is examined thoroughly in (Böhnert 2020).
} 
The terms themselves are generated by experienced animal-handlers like farmers or veterinarians who are shown video-recordings of pigs and tasked with describing the "'body language' apparent in the entire demeanour of an animal" (Wemelsfelder et al. 2012, 3654).

In her programmatic writings, Wemelsfelder refers to philosophical notions by e.g. rejecting "models of animal behaviour and welfare [...] based on dualistic principles, as conceived by the seventeenth century French philosopher Descartes" (Wemelsfelder 1997, 76). She argues against a soley mechanistic, chemo-physical approach, i.e. considering animals only as "purely physical systems as we understand physical systems today" (Wemelsfelder 2001, 129). Wemelsfelder instead bases her research in philosophical assumptions about the categorical comprehensibility of other minds adapted from Wittgenstein's private language argument (Wemelsfelder et al. 2001, 219).

The application of key characteristics of Classic Ethology to QBA enables philosophers of science to identify and systematise basic assumptions of animal research approaches that are concerned with animal subjectivity. Additionally, in comparison to historical approaches, distinctive features of today's research concerning animal subjectivity can become more visible.

I will outline the possibilities by applying the three key characteristics from the analysis of Lorenz' and Tinbergen's methodological signatures:

1. The concept of phylogenetic kinship: Because of the explicit use of subjective terminology, QBA researchers feel compelled to distance themselves from allegations of anthropomorphism. As shown above, the suspicion of anthropomorphism can only be connected with the use of subjective terminology only if a categorical anthropological difference is assumed. Wemelsfelder tackles possible suspicions by upholding the notion of the evolutionary continuum: "Careful observation of an animal's behavioural expression (is it nervous, is it relaxed?) should decrease, not increase, the risk of projecting human fears and preferences. The description of animal expressive repertoires throughout the evolutionary continuum could generate information about the evolution of emotion, and help prevent the postulation of arbitrary "cut-off points"' (Wemelsfelder 2001, 135). The assessment of animal subjectivity is presented not only as a means to determine factors relevant for animal welfare in the disciplinary framework of Applied Ethology, but also as a prerequisite for research in evolutionary biology.

2. Methodological and spatial requirements: Tough QBA explicitly assesses domesticated animals living in man-made environments, its methodology is similar to Lorenz' and Tinbergen's in regard to the question of expertise. Even contemporary critics of subjectrelated approaches in applied Ethology stress the importance of experience and practice in observing animal behaviour (Tuyttens et al. 2014, 278).

In QBA, video recordings replace the observers' presence, thus render the observation of the same behaviour possible for everyone who is given access to the recordings. This research situation shows characteristics of laboratory research (continuous presence of the object of research, miniaturization of the natural phenomenon by technical means, phenomenal time sequences are replaced by social ones (Knorr-Cetina 2002, 47)) as well as of field research (observation of complex and variable phenomena (Kohler 2002)). Hence, QBA turns out to be an overlap of opposing scientific cultural terrains (Köchy 2010, 167), especially when considering the fact, that the observed entities are products of nature as well as of human culture. It is worth taking a closer look at the anthropogenic aspects of animal behaviour in Applied Ethology and the interpretation of domesticated animals in contrast to wild ones. 
In regard to observational methodology, QBA is much more reliant on both technological means and statistics than Lorenz or Tinbergen. QBA uses a combination of statistical teqchniques to both quantify qualitative descriptions of animal behaviour (Wemelsfelder et al. 2001, 210-213) and also to test their reliability and validity. The statistically proven quantifiability of qualitative terminology is supposed to legitimise the use of this terminology. Examining the quantification of qualitative research can be linked to the discussion about mechanism in biological research in general (e.g. Kaiser and Craver 2013).

3. The semantic content of the concept of subjective terminology: At this point, QBA does not have a fixed set of terms or a unified methodology of creating them. Usually, emotional terms are used (Des Boyer Roches et al. 2018; Minero et al. 2018), but there is also research regarding temperament (Parham et al. 2019), or terminology based on human mental medical conditions like depression (Harvey et al. 2019). The processes by which sets of terms are compiled also differ: The terminology is either defined in the process of the actual behaviour assessment (Patel et al. 2019) or based on a "pre-fixed list of descriptors" (Grosso et al. 2016, 52), selected from existing ethological literature and revised by experts. QBA today is a method on the level of journal science, "bear[ing] the imprint of the provisional and personal" (Fleck 1981, 118). For future research, it would be interesting to investigate processes of standardisation and unification of QBA in regard to particular species.

\section{Concluding Remarks}

The aim of this paper was to use the analysis of historical positions to determine key characteristics of Classic Ethology by applying the tool of methodological signatures. The basic question in animal behaviour research is the adequate destruction and analysis of animal behaviour. By analysing Lorenz' and Tinbergen's research approaches I showed the epistemological, methodological and ontological basic assumptions that constitute the (de)legitimisation of subjective terminology. Those basic assumptions were used to define three key characteristics of ethological research concerned with animal subjectivity: The concept of phylogenetic kinship, temporal and spatial requirements of research and the semantic content of the concept of subjective terminology.

The fruitfulness of applying the tool of methodological signatures to examine current animal behaviour research was shown by the example of QBA. The transfer of the key characteristics highlights the distinctive features of QBA's research approach, e.g. the opportunities of audio-visual technology, while still being connected to a broader framework of ontological assumptions like the evolutionary continuum or the necessity of experienced observers. An extension of the scope of investigation to other ethological research approaches, their stance towards animal subjectivity and the associated basic assumptions seems productive for future studies in the history and philosophy of biology.

Acknowledgements The author would like to thank the research group Integrative Biophilosophie at the University of Kassel, especially Kristian Köchy, Robert Meunier and Martin Böhnert for their valuable advice on previous work on this topic, the colloquium under David Löwenstein at the Friedrich-SchillerUniversität Jena for constructive criticism of an early draft of this paper, and the anonymous referees for their helpful comments.

Funding Open Access funding enabled and organized by Projekt DEAL. 
Open Access This article is licensed under a Creative Commons Attribution 4.0 International License, which permits use, sharing, adaptation, distribution and reproduction in any medium or format, as long as you give appropriate credit to the original author(s) and the source, provide a link to the Creative Commons licence, and indicate if changes were made. The images or other third party material in this article are included in the article's Creative Commons licence, unless indicated otherwise in a credit line to the material. If material is not included in the article's Creative Commons licence and your intended use is not permitted by statutory regulation or exceeds the permitted use, you will need to obtain permission directly from the copyright holder. To view a copy of this licence, visit http://creativecommons.org/licenses/by/4.0/.

\section{References}

Arena, L., Wemelsfelder, F., Messori, S., Ferri, N., \& Barnard, S. (2017). Application of free choice profiling to assess the emotional state of dogs housed in shelter environments. Applied Animal Behaviour Science, 195, 72-79. https://doi.org/10.1016/j.applanim.2017.06.005.

Böhnert, M. (2020). Methodologische Signaturen: Ein philosophischer Versuch zur Systematisierung der empirischen Erforschung des Geistes von Tieren. Paderborn: Mentis.

Böhnert, M., \& Hilbert, C. (2018). "Other minds than ours": a controversial discussion on the limits and possibilities of comparative psychology in the light of C. Lloyd Morgan's work. History and philosophy of the life sciences, 40, 1-28. https://doi.org/10.1007/s40656-018-0211-4.

Burkhardt, R. W. (2005). Patterns of behavior: Konrad Lorenz, Niko Tinbergen, and the founding of ethology. Chicago, IL: University of Chicago Press.

von Cranach, A., \& Lorenz, K. (Eds.). (1992). Die Naturwissenschaft vom Menschen: Eine Einführung in die vergleichende Verhaltensforschung; das „Russische Manuskript“ (1944-1948). München: Piper.

de Des Boyer Roches, A., Lussert, A., Faure, M., Herry, V., Rainard, P., Durand, D., et al. (2018). Dairy cows under experimentally-induced Escherichia coli mastitis show negative emotional states assessed through Qualitative Behaviour Assessment. Applied Animal Behaviour Science, 206, 1-11. https://doi. org/10.1016/j.applanim.2018.06.004.

Eibl-Eibesfeldt, I. (1984). Konrad Lorenz (*1903). In Tierpsychologie: Die biologische Erforschung tierischen und menschlichen Verhaltens (pp. 66-82, Kindlers „Psychologie des zwanzigsten Jahrhunderts"). Weinheim: Beltz.

Fleck, L. (1981). Genesis and development of a scientific fact. Chicago, London: University of Chicago Press.

Fleming, P. A., Paisley, C. L., Barnes, A. L., \& Wemelsfelder, F. (2013). Application of Qualitative Behavioural Assessment to horses during an endurance ride. Applied Animal Behaviour Science, 144, 80-88. https://doi.org/10.1016/j.applanim.2012.12.001.

Grosso, L., Battini, M., Wemelsfelder, F., Barbieri, S., Minero, M., Dalla Costa, E., et al. (2016). On-farm Qualitative Behaviour Assessment of dairy goats in different housing conditions. Applied Animal Behaviour Science, 180, 51-57. https://doi.org/10.1016/j.applanim.2016.04.013.

Harvey, N. D., Moesta, A., Kappel, S., Wongsaengchan, C., Harris, H., Craigon, P. J., et al. (2019). Could greater time spent displaying waking inactivity in the home environment be a marker for a depressionlike state in the domestic dog? Animals: an Open Access Journal From MDPI. https://doi.org/10.3390/ ani9070420.

Hilbert, C. (2018). Das Problem des Anthropomorphismus in der Tierfoschung. Philosophie der Tierforschung: Band 3: Milieus und Akteure (pp. 139-186). Freiburg, München: Verlag Karl Alber.

ISAE Creativity Award 2017. https://www.applied-ethology.org/res/2017\%20ISAE\%20Creativity\%20Awa rd\%20-\%20Francoise\%20Wemelsfelder.pdf.

Kaiser, M. I., \& Craver, C. F. (2013). Mechanisms and Laws: Clarifying the Debate. In H.-K. Chao, S.-T. Chen, \& R. L. Millstein (Eds.), Mechanism and Causality in Biology and Economics (pp. 125-145, History, Philosophy and Theory of the Life Sciences, Vol. 3). Dordrecht: Springer.

Kappeler, P. M. (2017). Verhaltensbiologie (4th ed.). Berlin, Heidelberg: Springer Spektrum.

Knorr-Cetina, K. (2002). Wissenskulturen: Ein Vergleich naturwissenschaftlicher Wissensformen (1st ed., Suhrkamp-Taschenbuch Wissenschaft, Vol. 1594). Frankfurt am Main: Suhrkamp.

Köchy, K. (2010). Feld, Beobachtung. In P. Sarasin, \& M. Sommer (Eds.), Evolution: Ein interdisziplinäres Handbuch (pp. 167-171). Stuttgart, Weimar: Verlag J.B. Metzler.

Köchy, K. (2016a). Erleben und Erkennen. Zur historischen Entwicklung der Forschungsprogramme in den Neurowissenschaften. In Das Leben: Historisch-systematische Studien zur Geschichte eines Begriffs (pp. 357-400, Religion und Aufklärung, Band 27). Tübingen: Mohr Siebeck. 
Köchy, K. (2016b). Scientist in Action: Jean-Henri Fabres Insektenforschung zwischen Feld und Labor. Methoden und Programme. In M. Böhnert, K. Köchy, \& M. Wunsch (Eds.), Philosophie der Tierforschung (Vol. 1, pp. 81-148). Freiburg: Verlag Karl Alber.

Köchy, K., Wunsch, M., \& Böhnert, M. (2016c). Einleitung: Philosophie der Tierforschung. Die methodologische Signatur von Forschungsprogrammen. In M. Böhnert, K. Köchy, \& M. Wunsch (Eds.), Philosophie der Tierforschung: Band 1: Methoden und Programme (pp. 9-19). Freiburg: Verlag Karl Alber.

Kohler, R. E. (2002). Place and practice in field biology. History of science; an annual review of literature, research and teaching, 40, 189-210. https://doi.org/10.1177/007327530204000204.

Kurth, M. (2016). Handeln nichtmenschliche Tiere? In Das Handeln der Tiere: Tierliche Agency im Fokus der Human-Animal Studies (pp. 7-42, Human-animal studies). Bielefeld: transcript.

Latour, B. (1987). Science in action: How to follow scientists and engineers through society. Cambridge, MA: Harvard University Press.

Lawrence, A. B. (2016). 6. Applied animal behaviour science and animal welfare: seeking the best balance between our science and its application. In Animals and us: 50 years and more of applied ethology (Vol. 20, pp. 133-152). Wageningen: Wageningen Academic Publishers.

Lijmbach, S. (1998). Animal subjectivity: A study into philosophy and theory of animal experience. Wageningen: Wageningen Academic Publishers.

Lorenz, K. (1937). Biologische Fragestellung in der Tierpsychologie. Zeitschrift für Tierpsychologie, 1, 24-32.

Lorenz, K. (1965a). Betrachtungen über das Erkennen der arteigenen Triebhandlungen der Vögel (1932). In Bd. 1: Über tierisches und menschliches Verhalten: aus dem Werdegang der Verhaltenslehre; gesammelte Abhandlungen (1118th ed., pp. 70-114, Piper Paperback). München: Piper.

Lorenz, K. (1965b). Der Kumpan in der Umwelt des Vogels: Der Artgenosse als auslösendes Moment sozialer Verhaltensweisen (1935). In Bd. 1: Über tierisches und menschliches Verhalten: aus dem Werdegang der Verhaltenslehre; gesammelte Abhandlungen (1118th ed., pp. 115-282, Piper Paperback). München: Piper.

Lorenz, K. (1965c). Induktive und teleologische Psychologie (1942). In Bd. 1: Über tierisches und menschliches Verhalten: aus dem Werdegang der Verhaltenslehre; gesammelte Abhandlungen (1118th ed., pp. 380-401, Piper Paperback). München: Piper.

Lorenz, K. (1965d). Taxis und Instinkthandlung in der Eirollbewegung der Graugans (1938). In Bd. 1: Über tierisches und menschliches Verhalten: aus dem Werdegang der Verhaltenslehre; gesammelte Abhandlungen (1118th ed., pp. 343-379, Piper Paperback). München: Piper.

Lorenz, K. (1966a). Haben Tiere ein subjektives Erleben? (1963). In Bd. 2: Über tierisches und menschliches Verhalten: aus dem Werdegang der Verhaltenslehre; gesammelte Abhandlungen (4152nd ed., 395-374, Piper Paperback). München: Piper.

Lorenz, K. (1966b). Phylogenetische Anpassung und adaptive Modifikation des Verhaltens (1961). In Bd. 2: Über tierisches und menschliches Verhalten: aus dem Werdegang der Verhaltenslehre; gesammelte Abhandlungen (4152nd ed., pp. 301-358, Piper Paperback). München: Piper.

Lorenz, K. (1978). Vergleichende Verhaltensforschung: Grundlagen d. Ethologie. Wien, New York: Springer.

Lorenz, K., \& von Cranach, A. (1996). The natural science of the human species: An introduction to comparative behavioral research; the "Russian Manuscript" (1944-1948). Cambridge, MA: MIT Press.

Meyer-Holzapfel, M. (1984). Die Geburt der Ethologie. In Tierpsychologie: Die biologische Erforschung tierischen und menschlichen Verhaltens (pp. 23-36, Kindlers „Psychologie des zwanzigsten Jahrhunderts"). Weinheim: Beltz.

Minero, M., Dalla Costa, E., Dai, F., Canali, E., Barbieri, S., Zanella, A., et al. (2018). Using qualitative behaviour assessment (QBA) to explore the emotional state of horses and its association with humananimal relationship. Applied Animal Behaviour Science, 204, 53-59. https://doi.org/10.1016/j.appla nim.2018.04.008.

Minero, M., Dalla Costa, E., Dai, F., Murray, L. A. M., Canali, E., \& Wemelsfelder, F. (2016). Use of Qualitative Behaviour Assessment as an indicator of welfare in donkeys. Applied Animal Behaviour Science, 174, 147-153. https://doi.org/10.1016/j.applanim.2015.10.010.

Morton, D. B., Berghardt, G. M., \& Smith, J. A. (1990). Animals, science, and ethics-Section III. Critical anthropomorphism, animal suffering, and the ecological context. The Hastings Center report, 20(3), S13-9.

Naguib, M. (2006). Methoden der Verhaltensbiologie (Springer-Lehrbuch). Berlin, Heidelberg: Springer.

Parham, J. T., Tanner, A. E., Wahlberg, M. L., Grandin, T., \& Lewis, R. M. (2019). Subjective methods to quantify temperament in beef cattle are insensitive to the number and biases of observers. Applied Animal Behaviour Science, 212, 30-35. https://doi.org/10.1016/j.applanim.2019.01.005. 
Patel, F., Wemelsfelder, F., \& Ward, S. J. (2019). Using qualitative behaviour assessment to investigate human-animal relationships in zoo-housed giraffes (Giraffa camelopardalis). Animals: an Open Access Journal from MDPI. https://doi.org/10.3390/ani9060381.

Proctor, H. S., Carder, G., \& Cornish, A. R. (2013). Searching for animal sentience: A systematic review of the scientific literature. Animals: an Open Access Journal from MDPI, 3, 882-906. https://doi.org/10. 3390/ani3030882.

Rault, J.-L., \& Doyle, R. (2016). 5. Cognitive approaches and new technologies: changing methodologies in applied ethology. In Animals and us: 50 years and more of applied ethology (Vol. 33, pp. 113-132). Wageningen: Wageningen Academic Publishers.

Rutherford, K. M. D., Donald, R. D., Lawrence, A. B., \& Wemelsfelder, F. (2012). Qualitative Behavioural Assessment of emotionality in pigs. Applied Animal Behaviour Science, 139, 218-224. https://doi.org/ 10.1016/j.applanim.2012.04.004.

Schmitz, F. (2014). Tierethik - Eine Einführung. In Tierethik: Grundlagentexte (pp. 13-73, SuhrkampTaschenbuch Wissenschaft, Vol. 2082). Berlin: Suhrkamp.

Taylor, N. (2011). Anthropomorphism and the Animal Subject. In Anthropocentrism: Humans, animals, environments (pp. 265-279, Human-animal studies, vol. 12). Leiden: Brill.

Tinbergen, N. (1942). An Objectivistic study of the innate behaviour of animals. Bibliotheca Biotheoretica, 1(2), 37-98.

Tinbergen, N. (1963). On aims and methods of Ethology. Zeitschrift für Tierpsychologie, 20, 410-433. https://doi.org/10.1111/j.1439-0310.1963.tb01161.x.

Tinbergen, N. (1966). Instinktlehre: Vergleichende Erforschung angeborenen Verhaltens (4th ed.): Parey.

Tinbergen, N. (1978). Ethologie. Das Tier in seiner Welt. (Band 2: Laborversuche und Schriften zur Ethologie) (pp. 138-168). München: Piper.

Toepfer, G. (2011). Historisches Wörterbuch der Biologie: Geschichte und Theorie der biologischen Grundbegriffe. Band 1: Analogie - Ganzheit (Historisches Wörterbuch der Biologie, Geschichte und Theorie der biologischen Grundbegriffe / Georg Toepfer ; Bd. 1). Stuttgart, Weimar: Verlag J. B. Metzler.

Tuyttens, F. A. M., de Graaf, S., Heerkens, J. L. T., Jacobs, L., Nalon, E., Ott, S., et al. (2014). Observer bias in animal behaviour research: can we believe what we score, if we score what we believe? Animal Behaviour, 90, 273-280. https://doi.org/10.1016/j.anbehav.2014.02.007.

Waal, F. B. M. de. (2006). Primates and philosophers: How morality evolved (The University Center for human values series). Princeton, NJ: Princeton University Press.

Wemelsfelder, F. (1997). The scientific validity of subjective concepts in models of animal welfare. Applied Animal Behaviour Science, 53, 75-88. https://doi.org/10.1016/S0168-1591(96)01152-5.

Wemelsfelder, F. (2001a). The inside and outside aspects of consciousness: complementary approaches to the study of animal emotion. Animal Welfare, 10 (Special Issue: Consciousness, cognition and animal welfare), 129-139.

Wemelsfelder, F., Hunter, A. E., Paul, E. S., \& Lawrence, A. B. (2012). Assessing pig body language: agreement and consistency between pig farmers, veterinarians, and animal activists. Journal of Animal Science, 90, 3652-3665. https://doi.org/10.2527/jas.2011-4691.

Wemelsfelder, F., Hunter, E. A., Mendl, M. T., \& Lawrence, A. B. (2000). The spontaneous qualitative assessment of behavioural expressions in pigs: first explorations of a novel methodology for integrative animal welfare measurement. Applied Animal Behaviour Science, 67, 193-215. https://doi.org/10. 1016/S0168-1591(99)00093-3.

Wemelsfelder, F., Hunter, T. E. A., Mendl, M. T., \& Lawrence, A. B. (2001). Assessing the 'whole animal': a free choice profiling approach. Animal Behaviour, 62, 209-220. https://doi.org/10.1006/anbe.2001. 1741.

Wild, M. (2013). Tierphilosophie zur Einführung (3rd ed., Zur Einführung, Vol. 351). Hamburg: Junius.

Wuketits, F. M. (1995). Die Entdeckung des Verhaltens: Eine Geschichte der Verhaltensforschung. Darmstadt: Wissenschaftliche Buchgesellschaft.

Wunsch, M. (2016). Instinktverhalten bei Tieren. Die Debatte zwischen Konrad Lorenz und Daniel Lehrman. In M. Böhnert, K. Köchy, \& M. Wunsch (Eds.), Philosophie der Tierforschung: Band 1: Methoden und Programme (pp. 277-339). Freiburg: Verlag Karl Alber.

Publisher's Note Springer Nature remains neutral with regard to jurisdictional claims in published maps and institutional affiliations. 